\title{
Wind Resource Assessment in the state of Arizona: Inventory, Capacity Factor, and Cost
}

\author{
Thomas L. Acker, Associate Professor of Mechanical Engineering \\ Susan K. Williams*, Assistant Professor, College of Business Administration \\ Earl P.N. Duque, Associate Professor of Mechanical Engineering \\ Grant Brummels, Spatial Analyst, Sustainable Energy Solutions \\ Jason Buechler, Graduate Student, Mechanical Engineering \\ Northern Arizona University, Flagstaff, Arizona, USA
}

\begin{abstract}
During the summer of 2003, the state of Arizona took delivery of a set of high-resolution wind energy maps that were developed with a meso-scale wind energy model coupled with wind data. The geographical information system data supplied with the wind maps was used to create a wind resource inventory that included wind energy potential, proximity to transmission lines, and land ownership. Four diverse sites were selected for further study, one predominantly class 3 , one predominantly class 4 , one predominantly class 5 , and one predominantly class 6. At each site, the capacity factor was determined, the seasonal influence was observed, and the real levelized cost of energy in 2005 dollars determined. As the wind class varied from 6 to 3 the levelized cost of energy ranged from 4.22 to 6.00 cents per $\mathrm{kWh}$. These results do not include the production tax credit or the renewable energy production incentive, do include adjustments for elevation, losses, and inflation, and are considered conservative. This paper documents the findings of the wind mapping process, describes the method and results of evaluating the most promising sites for wind development, and presents the cost of energy results.
\end{abstract}

Keywords: wind energy; capacity factor; cost of energy; wind energy assessment; wind maps;

* Corresponding author: email: sk.williams@ nau.edu, PO Box 15066, Northern Arizona University, Flagstaff, AZ 86011, Tel: 1-928-523-0940. Fax: 1-928-523-7331 


\section{Introduction}

In 2002 Arizona produced over 94,000,000 MWh of electricity with 62,600,000 MWh of in-state sales. Currently, Arizona is an exporter of electricity. The demand for electricity has been increasing in the state of Arizona at an average of 3.9\% annually from 1993-2002. Generation capacity has been increasing but at a lower rate of $2.8 \%$ during that same time period [1].

In March 2006, the Arizona Corporation Commission (ACC) proposed a new renewable portfolio standard (RPS) [2]. This new standard requires an increasing percentage of energy be generated by renewable energy sources so that by $2025,15 \%$ of electricity will be generated from renewable resources. This is a significant increase from the 2001 standard of $1.1 \%$ by 2007 . In addition, utilities will be annually graded on their contribution to this goal with the commissioners discussing possible penalties if utilities are not adequately contributing [3]. Currently less than $1 \%$ of electricity is generated from renewable resources [1] (See Figure 1), so there is significant need for future wind and renewable energy development.

Arizona has an enviable solar resource with an average of 300 sunny days a year. However, since current photovoltaic energy costs are estimated to be $\$ 0.15-\$ 0.25 / \mathrm{kWh}$, there will likely be more development of wind, geothermal and biomass until solar costs further decline [4]. The cost of wind energy has decreased significantly. In the 1990s, the cost of wind turbines declined approximately $20 \%$ every time production doubled, which occurred every three years. This made wind energy the fastest growing energy technology in the 
1990s [5]. While Arizona is not in the top 20 U.S. states for wind resource [6] it does have a wind resource capable of supporting utility-scale development. "The larger contiguous areas of good-to-excellent resource are located in northern and eastern Arizona close to the eastern edge of the Mogollon Rim. Good-to-excellent wind resources are also found on the higher rims and ridge crests throughout the state." [7]

The wind resource for Arizona was first analyzed for the 1987 Wind Energy Resource Atlas for the United States. This map (See Figure 2) shows a few class 3 and 4 areas, and two class 5 areas along the Arizona-New Mexico border. It was noted that the best wind occurred in the winter in northern Arizona whereas in the southern Arizona mountainous areas winter and spring were the seasons of maximum wind power. [8]

In 1991, Elliot, et al performed an assessment for the entire United States, by state. Assuming a 10 diameter by 5 diameter turbine spacing, 50 meter hub height, $25 \%$ efficiency and $25 \%$ losses, and applying various exclusions, it was estimated that Arizona had 872 square kilometers of available land. The estimated power was 1,090 MW.

Higher-resolution maps and data became available in Arizona in August 2003. This work reports on progress made in analyzing Arizona's wind resource. Specifically,

- Created an inventory of the wind resource using GIS

- Determined the capacity factor and seasonality of the wind resource at four sites with different wind class regimes. 
- Determined the cost of energy for these four sites.

The sponsor for this work was the Arizona Wind Working Group (AzWWG) which was established in November of 2001 with support of the U.S. Department of Energy's Wind Powering America Program (Grant number: DE-FG65-03WA23843). The AzWWG is administered and led by the Sustainable Energy Solutions Group (SES) at Northern Arizona University (NAU). The group is composed of many stakeholders in the state including Native American tribes, coops, utilities, universities, state and federal officials, private businesses, environmental organizations, landowners, wind developers, and interested individuals. The goals of the AzWWG include determining the magnitude and geographic distribution of the wind energy resource available in Arizona and assessing the feasibility of commercial-scale development of Arizona's wind resource.

\section{Wind Maps and Data}

In order to assess the wind resource of an area, surface and upper air data are collected at several locations and then used to estimate Weibull distribution parameters. Landberg et al [9] provide an overview of wind resource estimation methods. Several studies in the US and around the world have used these methods. Potts et al [10] study the wind resource of western and central Massachusetts using WindMap, a GIS-assisted software package by Brower and Company. Jaramilla et al [11] estimate the wind resource of Baja California Sur, México utilizing a year of data from 15 wind stations. They found the levelized cost of production to be $4.5-6.2$ cents/kWh with a capacity factor of $25 \%$. 
There are several studies of the wind resource in Saudi Arabia. Rehman et al [12] perform a cost assessment of 20 sites determine the most cost efficient site. Rehman and Ahmad [13] describe seasonal and diurnal variations of five sites, wind energy production for two hub heights and capacity factors for various turbine sizes. Rehman et al [14] focus on an area in the northeastern part of the country where there are villages not yet connected to the national grid. They study $600 \mathrm{~kW}, 1000 \mathrm{~kW}$, and $1500 \mathrm{~kW}$ wind turbines from three manufacturers to determine which will perform best in that area.

Wind assessment is occurring in many other locations around the globe and include the Red Sea coast in Egypt [15], several locations in Kuwait [16], a wind atlas for Quebec province in Canada [17], and coastal wind in Granada, West Indies [18].

On a much larger scale, Hoogwik et al [19] performed a global, onshore wind-energy assessment. Using a $0.5^{\circ} \times 0.5^{\circ}$ (longitude, latitude) land-use grid they assess the theoretical, geographical, and technical potential of 17 world regions. They estimate the global potential for wind at approximate 6 times the 2001 world energy electricity consumption. The highest technical potential was found in the USA with the lowest in some regions of Africa, Eastern Europe and South East Asia.

One of the first tasks of the AzWWG was to purchase a high-resolution wind map. In August 2002, Northern Arizona University (NAU) contracted with TrueWind Solutions to buy a set of high-resolution wind maps. Using a modified meso-scale numerical weather prediction model coupled to a wind flow model, and 30-years of historical data, TrueWind 
created various maps and data for wind speed and wind power density. The maps and data delivered are:

- Mean annual and seasonal wind speed at 30, 50, 70, and 100 meters (m) and wind power density at $50 \mathrm{~m}$, each on a $200 \mathrm{~m}$ grid.

- Normalized monthly mean wind speed and Weibull k data at 30, 50, 70, and $100 \mathrm{~m}$ and wind power density at $50 \mathrm{~m}$ each produced on a 2 kilometer $(\mathrm{km})$ grid.

- Normalized annual and seasonal mean diurnal wind speed data at 30, 50, 70, and $100 \mathrm{~m}$ and wind power density at $50 \mathrm{~m}$, each on a $2 \mathrm{~km}$ grid.

- Overlays of state and national highways, major cities, State and Federal lands, and Native American Reservation boundaries.

Validation efforts by the National Renewable Energy Laboratory (NREL) used data from over 50 measurement stations [20]. The accuracy of the Arizona wind map was found to be comparable to other updated state maps, to within $10 \%$ of the annual average wind speed and $20 \%$ of annual wind power density at over $80 \%$ of individual validation sites. Electronic versions of the maps are posted at NAU's Sustainable Energy Solutions web site (http://ses.nau.edu). The complete set of wind maps and data were delivered to NAU at the end of August 2003.

Figure 3 shows a map of the wind power density $\left(\mathrm{W} / \mathrm{m}^{2}\right)$ at a $50 \mathrm{~m}$ hub height. The map indicates the wind power density via "wind class", tribal reservation boundaries, select cities, major transmission lines, and county boundaries. This map, as with all the Arizona 
wind maps, was designed for regional wind mapping and not for micrositing. It provides an indication of the magnitude of the wind energy resource and points to favorable wind resource areas, and provides much more resolution than the map shown in Figure 2.

NREL quantified the potential developable wind areas as summarized in Table 1 [20]. The "Raw" wind resource results from summing the total area of windy lands in each wind class and directly converting it to a wind electric potential through multiplying the land area by 5 MW per $\mathrm{km}^{2}$ of available windy land. The "Developable" wind capacity is computed by removing various exclusion areas such as

- $100 \%$ exclusions for National Park Service, Fish and Wildlife Service, State and private environmental lands, Wildlife, Wilderness, and Recreation Areas on federal land

- $50 \%$ exclusions for remaining U.S. Forest Service and Department of Defense lands

- $100 \%$ exclusions for urban areas and airports, wetlands, water bodies

- $50 \%$ exclusions for non ridge crest forest,

- $100 \%$ exclusions of slopes greater than $20 \%$

- $3 \mathrm{~km}$ buffer around airports and $100 \%$ exclusion areas

In total, about $35 \%$ of the raw class $3+$ lands and about $56 \%$ of the raw class $4+$ lands were excluded.

Table 1 also shows the expected wind resource at two of the more promising sites in Arizona: Gray Mountain (west of Cameron) and west of Springerville (see Figure 3 for locations). These resources, modest when compared to other states in the west, represent an im- 
portant and significant resource in a state with approximately 19,500 MW of summer generating capacity [1].

With these estimates of the wind energy resource potential in hand, the next steps identified by the AzWWG were to devise a method to rank the top sites for wind development and then evaluate the cost of energy at a few of these sites. These two tasks will be described in the following sections.

\section{AZ Wind Resource Inventory}

The TrueWind map data consists of both comma-delimited files and geographic information system (GIS) files. NAU utilized its GIS software to "mine" the data and then to rank the wind resource at various locations based upon specific attributes. The first step in mining the data was to divide the state into a grid of $4 \mathrm{~km}$ squares. Each 4-km "block" of land contains 400 of the 200-meter wind map data cells. Dividing the state into these blocks resulted in 18,710 distinct blocks, of which 4,370 contained at least one cell of windy land class 3 or greater. Assuming a conservative $5 \mathrm{MW}$ per $\mathrm{km}^{2}$ of windy land, a block with sufficient wind resource is capable of supporting $80 \mathrm{MW}$ of wind turbine capacity.

Six key attributes for wind energy development were selected for the inventory. The key attributes identified were

- wind power resource potential

- distance to transmission and substations

- distance to roads

Wind Resource Assessment in the state of Arizona: Inventory, Capacity Factor, and Cost $-8-$ 
- land use/ownership

- county

- tribal reservation information

To determine these attributes for each block, the GIS wind map data was combined with overlays of transmission and substation data, roadways, land use/ownership information (e.g., National Forest, Wilderness Area, State Trust Land, private land, etc.), tribal reservation boundaries, county boundaries, and city locations (urban areas). Except for the transmission and substation overlay, TrueWind provided all overlays along with the wind map data. The transmission and substation information was obtained from the Arizona Corporation Commission as a CAD (computer-aided design) file that was converted to GIS.

Assigning most of these attributes to each block of land was fairly straightforward. For example, with regard to transmission, an output variable was defined for each block of land to indicate whether or not any cell within the block was within 10 miles of a transmission line. Then, if a transmission line was within 10 miles of any cell in the block, the GIS software sets this variable to one; otherwise it is set to zero. In this way, each block of land can be "flagged" to indicate its proximity to transmission, substations, roads, type of land use/ownership, county(ies), and tribal reservation(s).

To determine the wind power resource potential for each block, a "Wind Power Number" $(W P N)$ was computed to quantify a given land block's wind power potential. The capacity of wind power that can be installed on any given block of land depends on the nature and magnitude of the wind resource, the terrain, the turbine characteristics and layout, and a 
number of other factors. Because the goal in this ranking process is simply to compare the wind power potential of the many blocks of land, it is not necessary to compute the wind power potential in exacting detail. Counting only the cells of windy land within a block (class 3 or better wind resource), the WPN was defined as follows:

$$
W P N=\frac{\sum_{i=3}^{7}\left(W P D_{i} \times A_{\text {rotor }} \times W L_{i} \times N\right)}{A_{\text {rotor }} \times N}=\sum_{i=3}^{7}\left(W P D_{i} \times W L_{i}\right)
$$

where

$$
\begin{aligned}
& W P D_{i}=\text { mean wind power density for wind class } i\left(\mathrm{~W} / \mathrm{m}^{2}\right) \\
& A_{\text {rotor }}=\text { swept area of rotor }\left(\mathrm{m}^{2}\right) \\
& W L_{i}=\text { area of windy land in block of wind class } i\left(\mathrm{~km}^{2}\right) \text {; computed by multiplying } \\
& \text { the number of cells within the block with this wind resource by the cell area. } \\
& N=\text { number of turbines that can be installed per unit land area }\left(1 / \mathrm{km}^{2}\right) \\
& i=\text { wind power class ranging from } 3 \text { to } 7
\end{aligned}
$$

For the purpose of this analysis, it was assumed that the number of wind turbines per square kilometer is the same on all blocks of land, and that identical turbines are used (thus $A_{\text {rotor }}$ and $N$ cancel out of the above equation). The resulting WPN physically represents an approximate wind power potential and has the unit of Watts. Given to the simplifying assumptions, the WPN is used only to compare the relative potential of blocks of land and not as an indicator of the actual wind power potential. 
Due to the irregular shape of the state border, many blocks of land along the border have less than $16 \mathrm{~km}^{2}$ of land area. Thus, it is necessary to normalize the $W P N$ to account for varying block area. The normalized WPN (denoted $N W P N$ ) is computed as follows:

$$
N W P N=\frac{W P N}{W P N 3}
$$

where

WPN3 = wind power number for a block of land in which ALL cells within the block have a class 3 rating. $W P N 3=W P D_{3} \times$ Area $_{\text {block }}$

$W P D_{3}=$ minimum wind power density of a class 3 resource; equal to $300 \mathrm{~W} / \mathrm{m}^{2}$ Area $_{\text {block }}=$ area of land within block in $\mathrm{km}^{2}$

The NWPN may be used to compare land blocks of different areas and allows for easy interpretation. If a block has an $N W P N$ of 1.0, then the block has a minimally class 3 wind resource. Similarly, if a block's $N W P N$ is equal to $1.33,1.67$, or 2.0 , then on average the block has a class 4, 5, or 6 resource, respectively. There are 107 blocks within Arizona that have an NWPN greater than or equal to 1.0, the top five of which are shown in Table 2. One of the blocks is rated class 5, five blocks are rated class 4, and the remaining 102 are rated as class 3 .

Calculating the NWPN and assigning the appropriate flagged attributes to each block of land was accomplished through use of NAU's GIS software. A GIS model was created that could analyze the data and write the results to an ASCII text file. This text file can be imported into a spreadsheet program for further analysis and interpretation. Because of the 
various flagged attributes (e.g., land use, county, proximity to transmission, etc.), the data in the spreadsheet program can easily be sorted, filtered, and ordered. Table 2 shows an ordering that is only one of many possible ways to view the data. For instance, using the flagged attributes, one could easily focus in on blocks of land that contain State Trust lands only and are within 10 miles of the transmission grid, then order them by NWPN. None of the NREL exclusions have been applied to this data. However, to the extent that each of the exclusion categories (e.g., wilderness lands, etc.) has been assigned as attributes, the exclusions can be applied within the inventory spreadsheet file.

\section{Capacity factor and cost of energy analysis}

Four locations were selected for further study and their approximate locations are illustrated in Figure 3. These sites were selected because of the diverse geographic characteristics, varied location within the state, and the diverse wind resource potential.

- West of Cameron in northern Arizona, Coconino County and the Navajo Reservation. This site is also known as Gray Mountain. It is primarily owned by the Navajo Nation with some privately owned land. One of the best wind energy sites in Arizona, there is significant Class 5 and above wind resource. Two blocks were selected from this area. One was predominantly class 5 and the other predominantly class 6.

- West of Springerville is in the eastern part of the state and is primarily State Trust land. There is very little Class 5 and above wind resource but there is significant Class 4 resource. 
- Northwest of Kingman is in the western part of the state. The wind resource there is primarily Class 3 .

These 4 locations were analyzed to determine the capacity factor, the seasonality, and the cost of energy.

\section{Capacity Factor and Seasonality}

The capacity factor (CF) is defined as the ratio of the estimated annual energy output of a wind farm to its output if all turbines were running at full rated capacity for the entire year. In order to determine the $\mathrm{CF}$ at each site, the wind map data was utilized along with a GE Wind Energy 1.5 s turbine power curve to estimate the energy output. The GE turbine was assumed to have a $77 \mathrm{~m}$ rotor, and the power curve for an elevation (i.e., air density) appropriate to each site.

At each site, nine grid points in close proximity were selected from the GIS data, and the Weibull parameters from the wind map data at 30, 50, 70 and 100 meter hub height were used to determine an average distribution of wind speeds at each of the nine points. This distribution was then transformed into an estimated annual energy output by using the GE power curve, and finally an annual gross capacity factor was computed. The nine points for the two sites West of Cameron are shown in Figure 4. As shown in Figure 5, the variation in the capacity factor computed from the nine points at each site was between $2 \%$ and $2.5 \%$ at the class 4-6 sites. There was less variation at the Kingman (class 3) site. The gross CF 
at each location was reduced by $10 \%$ to account for array losses, soiling, availability, etc. and this net capacity factor was used in the cost of energy calculations.

Figure 6 shows the seasonal variation in capacity factor at each site. The Springerville and Cameron sites are similar with the highest capacity factor occurring during the spring and the lowest in winter and summer. At the Kingman site winter is the best season for wind. Figure 7 shows the gross capacity factor at each of the four sites plotted versus hub height.

\section{Cost of Energy Analysis}

The Cost of Energy (COE) was determined for each of these four sites. The tool employed to compute an estimate of the cost of energy was the NREL wind energy finance calculator http://analysis.nrel.gov/windfinance. There are 28 inputs to the model including general project parameters such as rated capacity, capacity factor, lifetime, and specific parameters related to capital costs, financing, operating expenses, taxes, and more. Identical inputs were used for the analysis at each site with the exception of the capacity factor (CF). A summary of some of the key assumptions is shown in Table 3.

A summary of the relevant parameters for each location, including the COE, is shown in Table 4. The levilized COE figures shown range from an average of 5.21 to 7.51 cents per $\mathrm{kWh}$ (in 2005 dollars), as the wind class varies from 6 to 3, respectively. These values are consistent with those published by the California Energy Commission in their Renewable Resources Development Report [21]. Accounting for tax incentives could reduce the cost per $\mathrm{kWh}$ by as much as 1.8 cents per $\mathrm{kWh}[22]$. 
The cost of energy results reported here are "bus bar" costs, and do not include transmission costs or ancillary services. Transmission costs are project specific and can be significant. Ancillary service costs (i.e., regulation, load following, unit commitment) can also affect COE. For some specific projects, these costs have been shown to range from $\$ 0.005$ to $\$ 0.55$ per $\mathrm{kWh}$, depending largely on the relative capacity of the wind farm to the transmission control area load [23].

\section{Conclusions}

Wind energy potential for the state of Arizona has been studied. A high-resolution wind map and data were delivered and was the basis for this study. The developable wind energy potential was estimated by NREL to be 23,290 MW of class 3 or higher, 2,630 MW of class 4 or higher, and $775 \mathrm{MW}$ of class 5 or higher winds. Using a GIS, a grid of $4 \times 4 \mathrm{~km}^{2}$ blocks was created across Arizona. The GIS and the wind map data were employed to create an inventory of the blocks that have windy land. Attributes inventoried for each block included amount of each wind class contained in the block, ownership information, distance to transmission, and a wind energy potential measurement.

Four of these blocks, each predominantly containing a wind resource from wind class 3-6, were selected for further study. The capacity factor for each block was determined using nine points within the block. A GE 1.5 s power curve was assumed. Using wind map data to compute the levelized cost of energy in 2005 dollars at these four sites within the state 
revealed estimates ranging from 5.21 to 7.51 cents per $\mathrm{kWh}$, as the wind class varies from 6 to 3 , without considering any tax incentives, transmission, or ancillary service costs.

Several additional studies are planned for the state of Arizona. The GIS and wind map will be used to apply development exclusions to the windy land inventory. The wind resource for each county will be determined; exclusions applied and wind farm economic benefits for that county will be estimated. Additional cost of energy analysis is planned including a cost comparison of generating wind energy in-state versus purchasing green energy for the renewable portfolio standard from out-of-state. 


\section{References}

[1] Energy Information Administration. State Electricity Profiles 2002. DOE/EIA0348(01)/2. Office of Coal, Nuclear, Electric and Alternate Fuels. US Department of Energy Washington, DC, January 2004. Accessed at www.eia.doe.gov.

[2] Arizona Corporation Commision. Renewable Energy Standard and Tariff. R-14-2-18. Decision 68566. March 14, 2006.

[3] Alltucker K. Ariz. Regulators toughen rules to boost supply of clean energy. The Arizona Republic. August 11, 2005.

[4] EERE US DOE. Learning About PV: The Myths of Solar Electricity. http://www1.eere.energy.gov/solar/myths.html accessed March 25,2006.

[5] Ackermann T, Söder L. Wind Energy Technology and Current Status: A Review. Renewable \& Sustainable Energy Reviews 2000; 4:315-374.

[6] Elliot DL, Wendell LL, Gower GL, An assessment of available windy land area and wind energy potential in the contiguous United States. US Department of Energy. In: American Wind Energy Association. Wind Energy Fact Sheet. http://www.awea.org/pubs/factsheets/top202001.pdf

[7] National Renewable Energy Lab. Arizona Wind Map. Wind Powering America, accessed March 22, 2006. www.eere.energy.gov/windandhydro/windpoweringamerica/maps_template.asp?stateab $=\mathrm{az}$.

[8] Elliott DL, Holladay CG, Barchet WR, Foote HP, Sandusky, WF. Wind energy resource atlas of the United States. DOE/CH 10093-4. Oct 1986. accessed http://rredc.nrel.gov/wind/pubs/atlas/atlas_index.html

[9] Landberg L, Myllerup L, Rathmann O, Petersen EL, Jøgensen BH, Badger J, Mortensen NG. Wind Resource Estimation - An Overview. Wind Energy 2003; 6:261271.

[10] Potts JR, Pierson SW, Mathisen PP, Hamel JR, Babau VC. Wind energy resource assessment of western and central Massachusetts. AIAA 2001-60. 2001 ASME Wind Energy Symposium, 20th, Aerospace Sciences Meeting and Exhibit, 39th, Reno, NV, Jan. 11-14, 2001, Collection of Technical Papers (A01-16933 03-44)

[11] Jaramillo OA, Saldaña, Miranda U. Wind power potential of Baja California Sur, México. Renewable Energy 2004; 29:2087-2100. 
[12] Rehman S, Halawani TO, Mohandes M. Wind power cost assessment at twenty locations in the kingdom of Saudi Arabia. Renewable Energy 2003; 28:573-583.

[13] Rehman S, Ahmad A. Assessment of wind energy potential for coastal locations of the Kingom of Saudi Arabia. Energy 2004; 29:1105-15.

[14] Rehman S, El-Amin IM, Ahmad F, Shaahid SM, Al-Shehri AM, Bakhashwain JM. Wind power resource assessment for Rafha, Saudi Arabia. Renewable and Sustainable Energy Reviews in press.

[15] Ahmad Shata AS, Hanitsch R. The potential of electricity generation on the east coast of Red Sea in Egypt. Renewable Energy in press.

[16] Al-Nassar W, Alhajraf S, Al-Enizi A, Al-Awadhi L. Potential wind power generation in the State of Kuwait. Renewable Energy 2005; 30: 2149-61.

[17] Ilinca A, McCarthy E, Chaumel JL, Rétiveau JL. Wind potential assessment of Quebec Province. Renewable Energy 2003; 28:1881-07.

[18] Weisser D. A wind energy analysis of Grenada: an estimation using the 'Weibull' density function. Renewable Energy 2003; 28:1803-12.

[19] Hoogwijk M, de Vries B, Turkenburg W. Assessment of the global and regional geographical, technical and economic potential of onshore wind energy. Energy Economics 2004; 26: 889-919.

[20] Schwartz M. Arizona Wind Resources, National Renewable Energy Laboratory, presentation to the Arizona Wind Working Group, Flagstaff, Arizona, August 6, 2003.

[21] California Energy Commission. Renewable Resources Development Report. 500-03080F, November 2003.

[22] Energy Policy Act of 2005, p. 1122, http://energy.senate.gov/public/_files/ConferenceReport0.pdf, July 27, 2005.

[23] Parsons B, Milligan M, Zavadil B, Brooks D, Kirby B, Dragoon K, Caldwell J. Grid Impacts of Wind Power: A Summary of Recent Studies in the United States. NREL/CP500-34318, June 2003. 


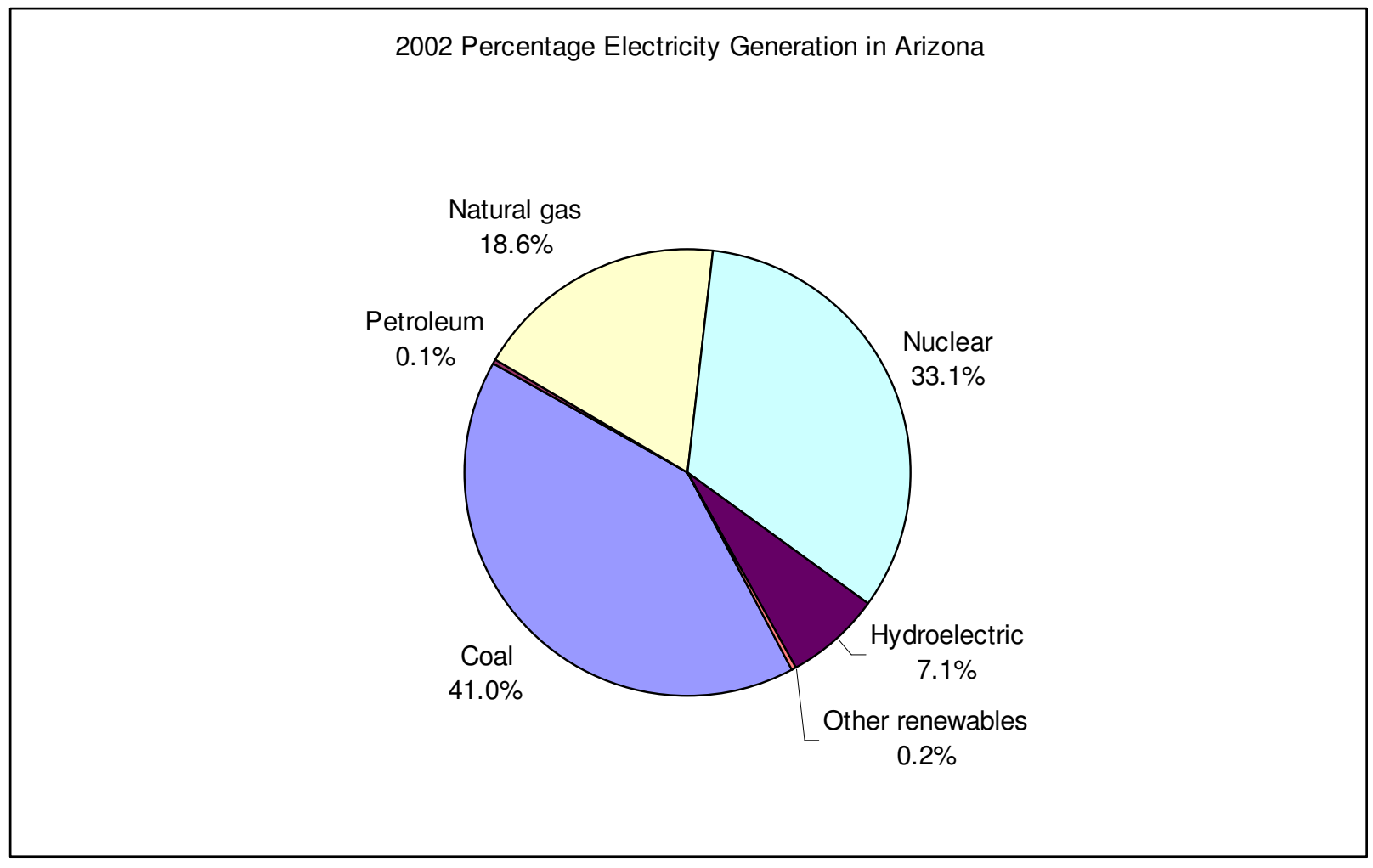

Figure 1 Arizona Electricity Generation by Energy Source 2002 


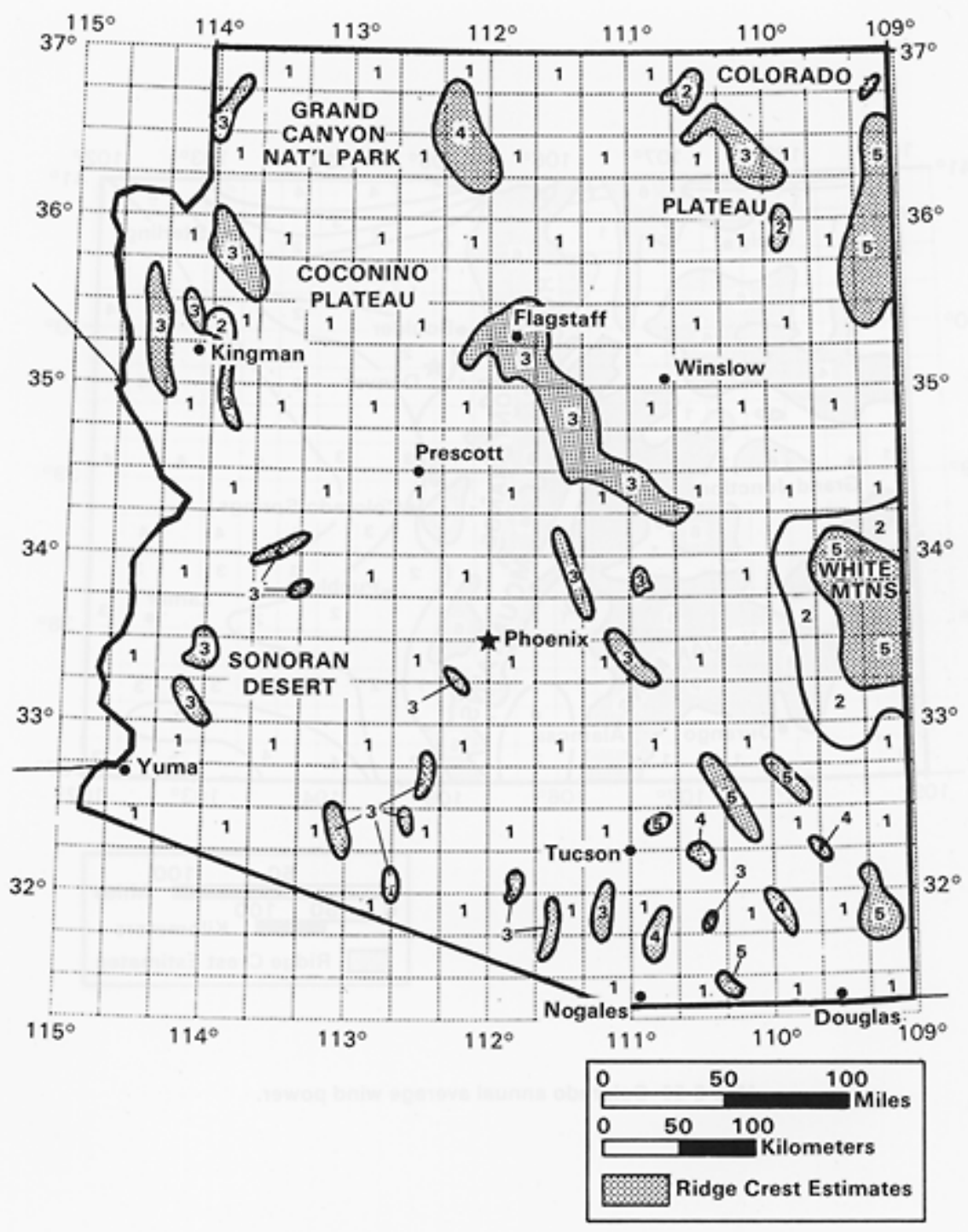

Figure 21987 Arizona Wind Map [6] 


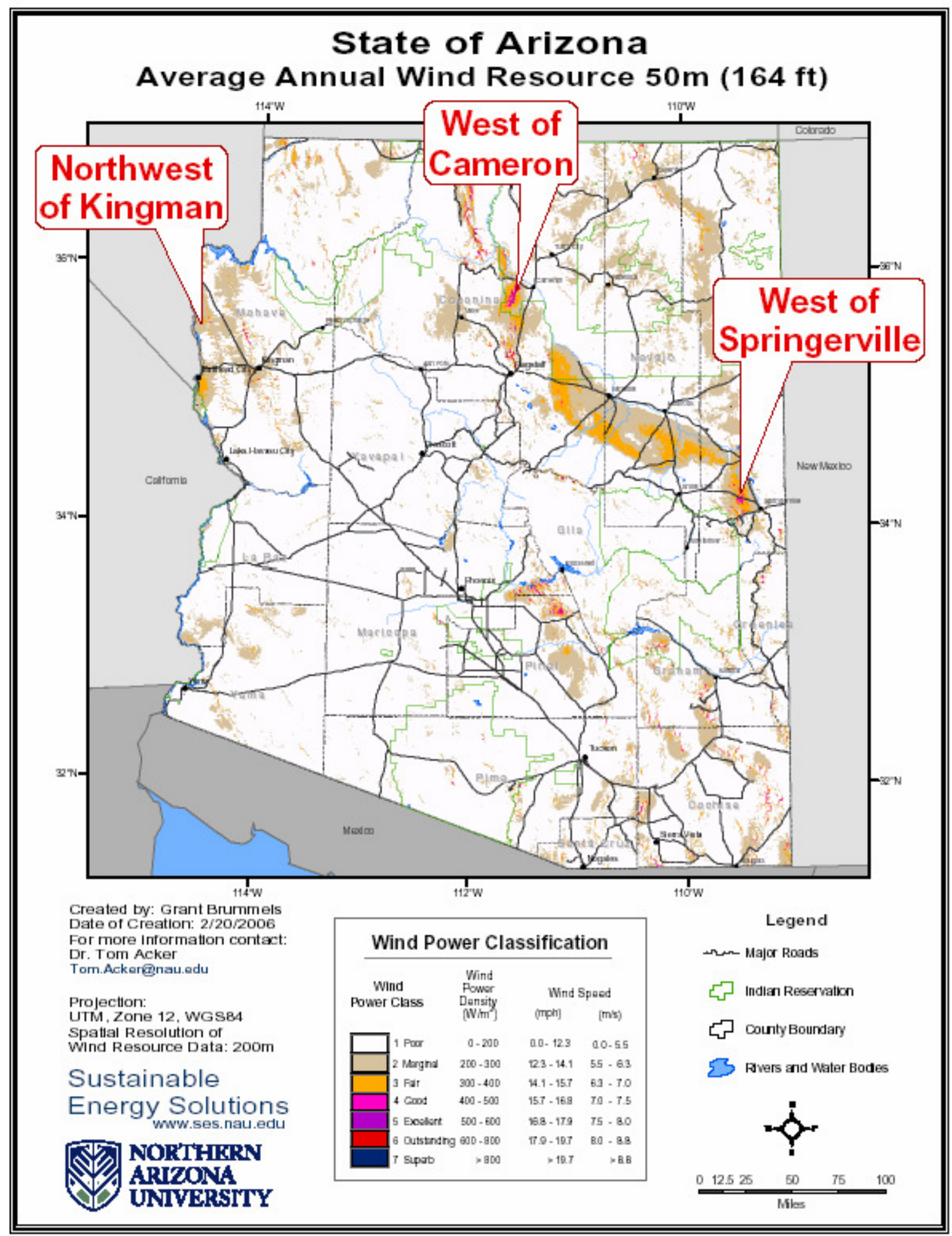

Figure 3 Arizona Wind Map 


\section{W of Cameron Capacity Factor Points}

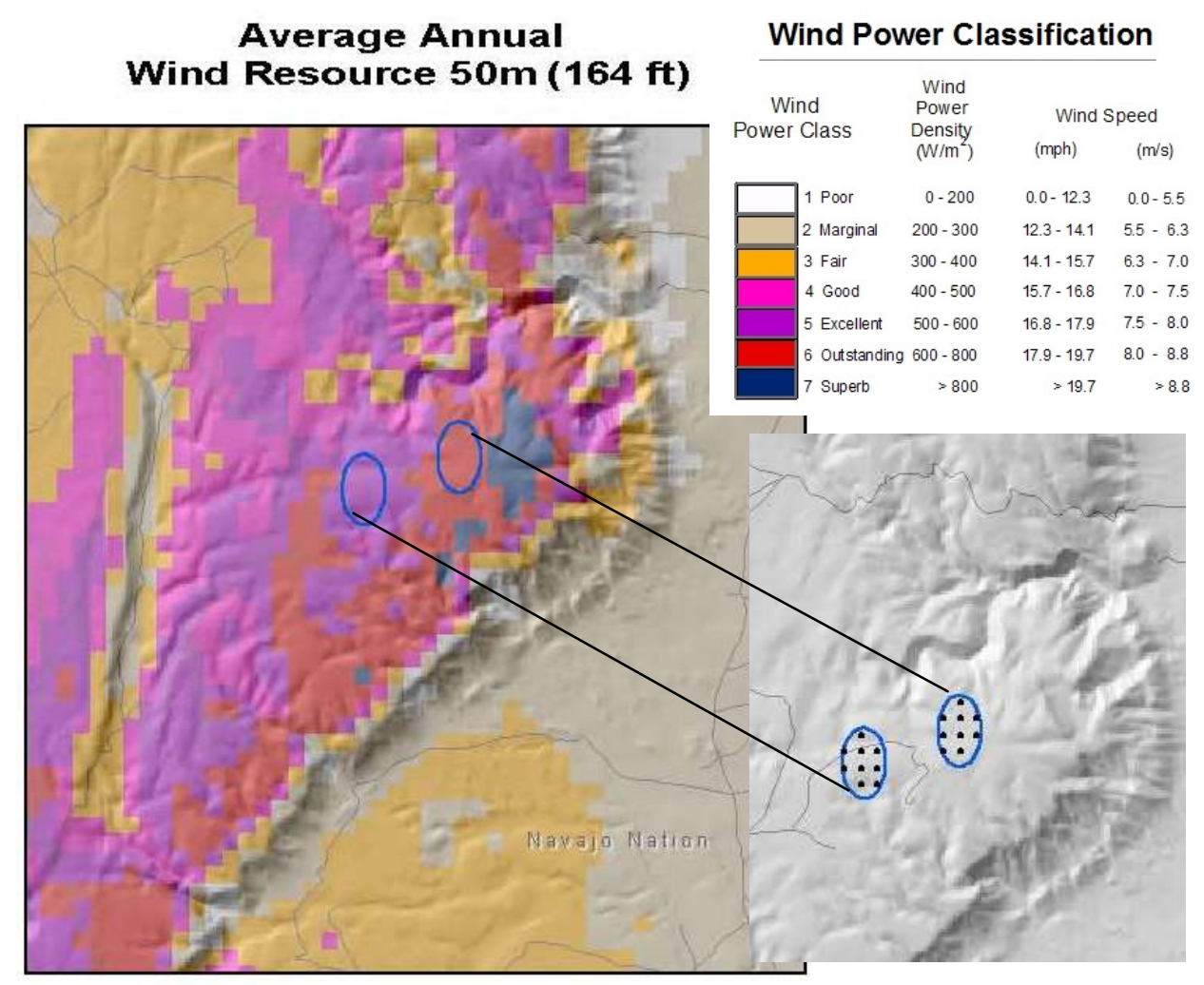

Figure 4 Capacity Factor Data Point for W of Cameron 


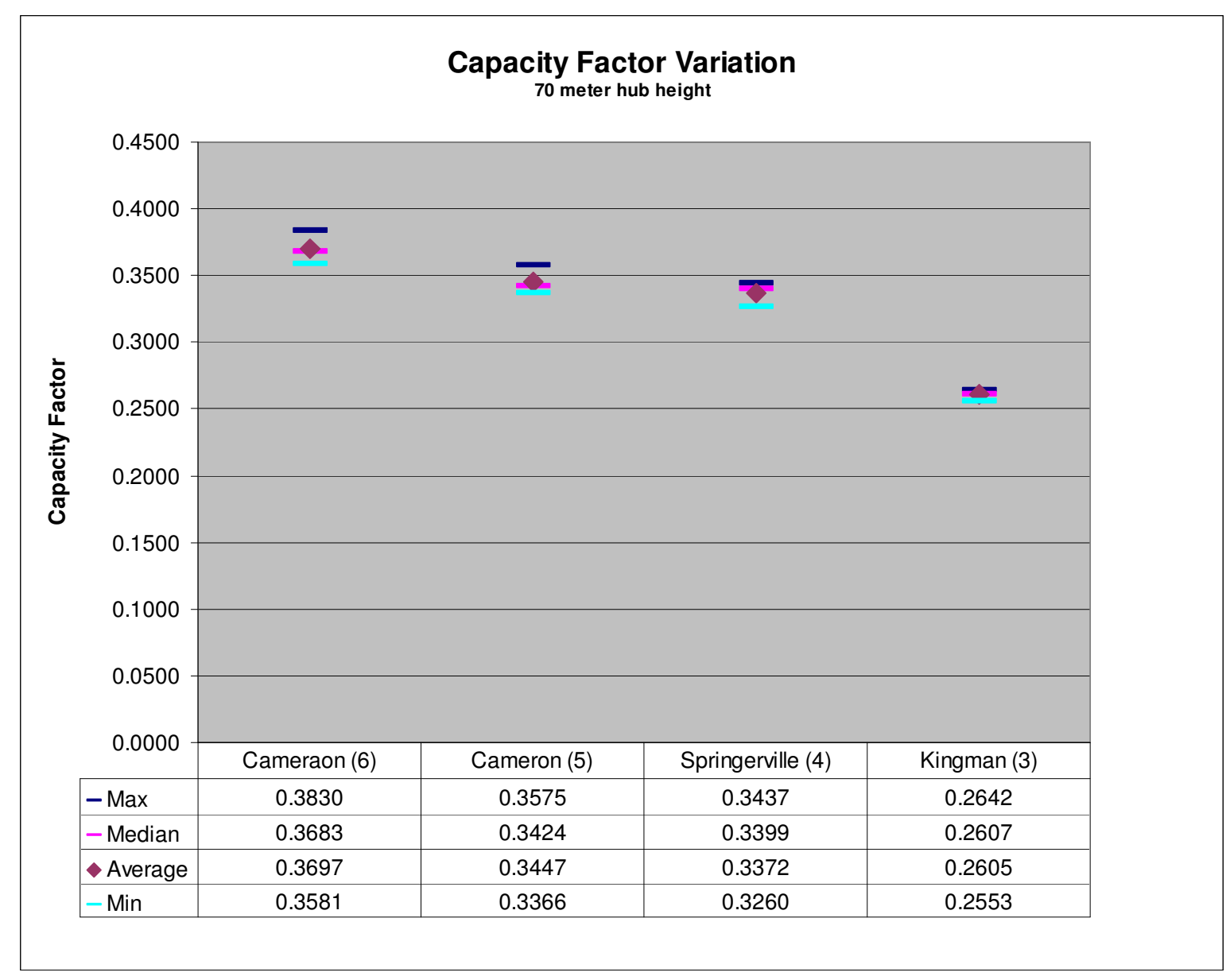

Figure 5 Capacity Factor Variation at four Sites 

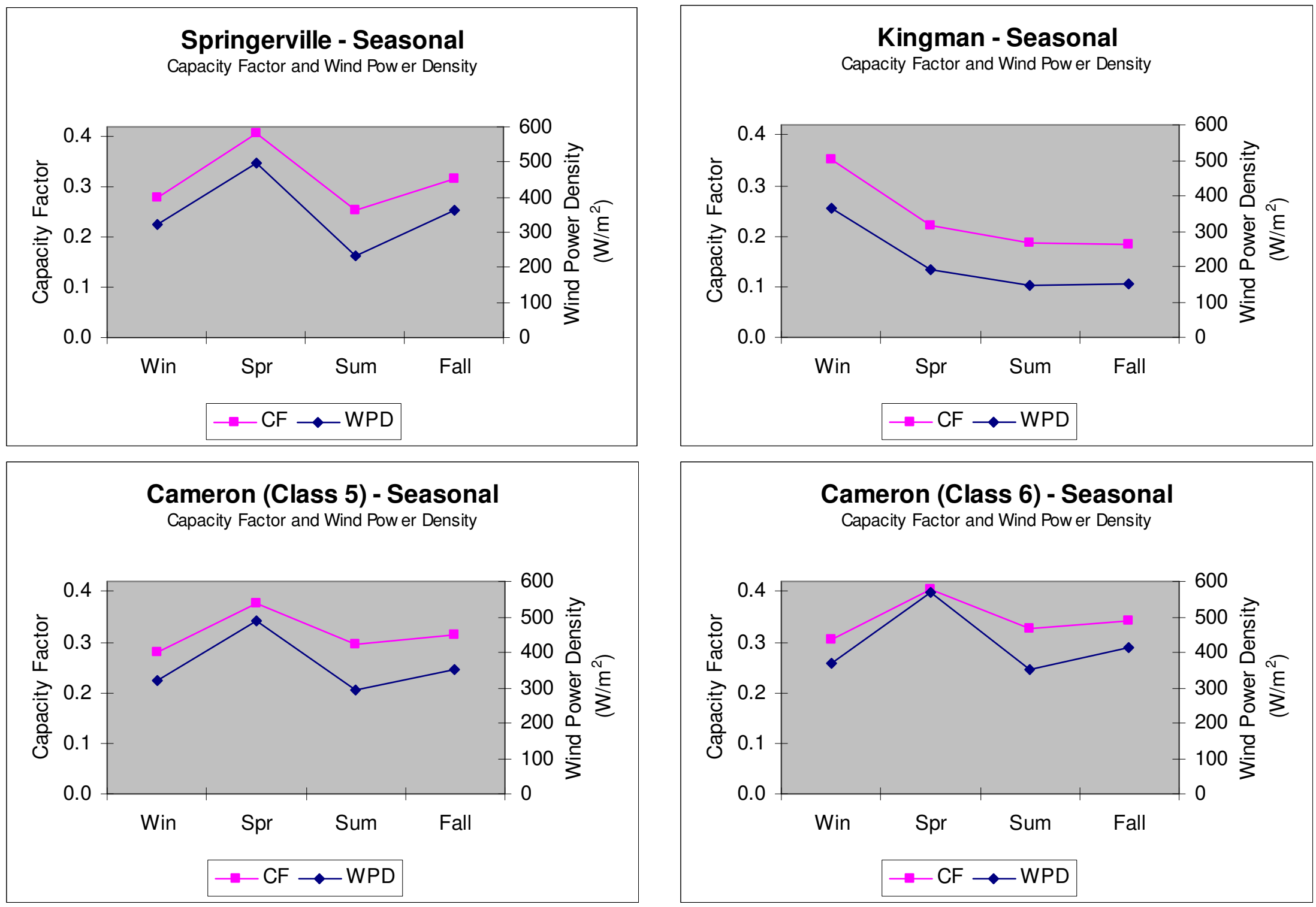

Figure 6 Seasonal Capacity Factors and Wind Power Density 


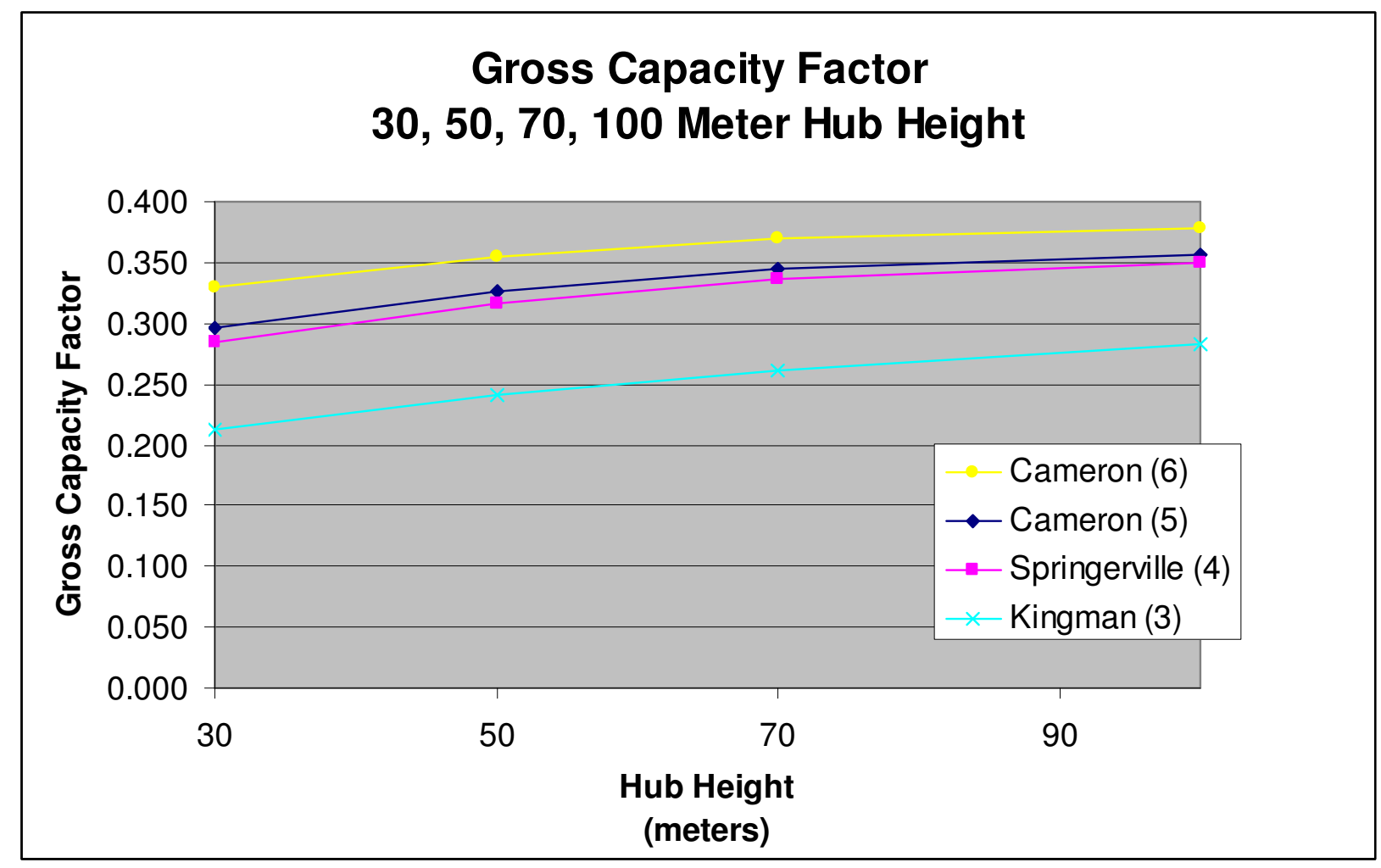

Figure 7 Gross Capacity Factors for Various Hub Heights 
Table 1 - Wind energy resource potential, both raw and developable, in the state of Arizona ${ }^{[7]}$

\begin{tabular}{ccccccc}
\hline Wind & \multicolumn{2}{c}{ Entire State of Arizona } & \multicolumn{2}{c}{ West of Cameron } & \multicolumn{2}{c}{ West of Springerville } \\
Class* & Raw & Developable & Raw & Developable & Raw & Developable \\
\hline Class 3 & $35430 \mathrm{MW}$ & $23290 \mathrm{MW}$ & & & & \\
\hline Class 4 + & $5980 \mathrm{MW}$ & $2630 \mathrm{MW}$ & $433 \mathrm{MW}$ & $433 \mathrm{MW}$ & $330 \mathrm{MW}$ & $299 \mathrm{MW}$ \\
\hline Class 5 & $2040 \mathrm{MW}$ & $775 \mathrm{MW}$ & $210 \mathrm{MW}$ & $210 \mathrm{MW}$ & $43 \mathrm{MW}$ & $37 \mathrm{MW}$ \\
\hline Class 6 + & $790 \mathrm{MW}$ & $235 \mathrm{MW}$ & $61 \mathrm{MW}$ & $61 \mathrm{MW}$ & $9 \mathrm{MW}$ & $8 \mathrm{MW}$ \\
\hline
\end{tabular}

$*$ Class $3+$ implies class 3 or greater; class $4+$ implies class 4 or greater, etc 
Table 2 - The top five rated land blocks within Arizona based on the NWPN

\begin{tabular}{lrcrccc}
\hline & & & & \multicolumn{2}{c}{ Land Ownership } \\
Block No. & NWPN & $\begin{array}{c}\text { Distance to Nearest } \\
\text { Power Line (meters) }\end{array}$ & Private & State Trust & $\begin{array}{c}\text { Navajo Indian } \\
\text { Reservation }\end{array}$ & $\begin{array}{c}\text { Indian } \\
\text { Allotments }\end{array}$ \\
\hline W of Cameron (3851) & 1.68 & 2926 & $10.8 \%$ & $0.0 \%$ & $87.5 \%$ & $1.8 \%$ \\
\hline W of Cameron (3979) & 1.46 & 1481 & $7.0 \%$ & $0.0 \%$ & $93.0 \%$ & $0.0 \%$ \\
\hline W of Cameron (4108) & 1.40 & 4893 & $2.0 \%$ & $0.0 \%$ & $98.0 \%$ & $0.0 \%$ \\
\hline W of Cameron (3722) & 1.40 & 6917 & $21.0 \%$ & $0.0 \%$ & $79.0 \%$ & $0.0 \%$ \\
\hline W of Springerville (9556) & 1.34 & 475 & $1.0 \%$ & $99.0 \%$ & $0.0 \%$ & $0.0 \%$ \\
\hline
\end{tabular}


Table 3 - Summary of key inputs to NREL Wind Energy Finance Calculator

\begin{tabular}{lll}
\hline $75 \mathrm{MW}$ project & 15-year financing & No PTC or REPI \\
\hline 2005 start date & Level mortgage & $3 \%$ inflation rate \\
\hline$\$ 1200 / \mathrm{kW}$ total capital costs & $80 \%$ debt percentage & Target IRR $15.22 \%$ \\
\hline$\$ 20 / \mathrm{kW} / \mathrm{yr}$ total operating costs & $6.8 \%$ interest on debt & Discount rate $5.5 \%$ \\
\hline
\end{tabular}

Wind Resource Assessment in the state of Arizona: Inventory, Capacity Factor, and Cost 
Table 4 - Capacity factor and cost of energy results at three sites in Arizona

\begin{tabular}{lcccc}
\hline Location & $\begin{array}{c}\text { Real Levelized } \\
\text { COE } \\
(\text { cents/kWh) }\end{array}$ & $\begin{array}{c}\text { Wind } \\
\text { Power } \\
\text { Class }\end{array}$ & $\begin{array}{c}\text { Capacity Factor } \\
\text { No Losses } \\
\text { at 70 m }\end{array}$ & $\begin{array}{c}\text { Capacity Factor } \\
10 \% \text { reduction } \\
\text { due to losses at 70 m }\end{array}$ \\
\hline West of Cameron & $5.09-5.46$ & 6 & $37.0 \%$ & $33.3 \%$ \\
\hline West of Cameron & $5.46-5.80$ & 5 & $34.5 \%$ & $31.0 \%$ \\
\hline West of Springerville & $5.69-6.00$ & 4 & $33.7 \%$ & $30.3 \%$ \\
\hline Northwest of Kingman & $7.38-7.64$ & 3 & $26.1 \%$ & $23.4 \%$ \\
\hline
\end{tabular}

